\title{
Community structure and functional diversity of polypores (Basidiomycota) in the Atlantic Forest of Santa Catarina State, Brazil
}

\author{
Marco A. Borba-Silva ${ }^{1^{*}}$ \\ Elisandro Ricardo Drechsler-Santos ${ }^{1}$ \\ Gerardo Lucio Robledo ${ }^{2}$ \\ ${ }^{1}$ Universidade Federal de Santa Catarina, Departamento de Botânica \\ Campus Universitário Reitor João David Ferreira Lima \\ Trindade, CEP 88040-960, Florianópolis - SC, Brasil \\ ${ }^{2}$ Laboratorio de Micología, Instituto Multidisciplinario de Biología Vegetal, CONICET \\ Universidad Nacional de Córdoba, CC 495, CP 5000 Córdoba, Argentina \\ * Autor para correspondência \\ marcoborba64@gmail.com
}

Submetido em 04/03/2014

Aceito para publicação em 05/01/2015

\section{Resumo}

Estrutura de comunidade e diversidade funcional de fungos poliporoides (Basidiomycota) na Mata Atlântica de Santa Catarina, Brasil. Estudos ecológicos têm sugerido que os diferentes grupos de espécies poliporoides, agindo como parasitas e/ou saprófitas, degradam diferentes tipos de substratos. Estes grupos funcionais têm diferente capacidade de degradação e, portanto, diferentes papeis nos ecossistemas. O objetivo deste estudo foi descrever a comunidade de políporos decompositores de madeira da Mata Atlântica do Parque Nacional da Serra do Itajaí, no estado de Santa Catarina, a partir da composição de espécies e sua funcionalidade, inferida com base na "preferência" por substratos onde produzem as estruturas reprodutivas. Os dados sobre as espécies poliporoides e tipo de substratos foram amostrados em duas parcelas $(100 \times 50 \mathrm{~m})$. Foram identificadas 58 espécies entre 152 espécimes coletados. Foram identificados três grupos principais onde o primeiro grupo apresentou três espécies dominantes, um segundo grupo com cinco espécies subordinadas e um terceiro grupo com 50 espécies raras. As espécies foram ordenadas usando uma análise de correspondência baseado na frequência relativa dos diferentes tipos de substratos e tamanho médio do substrato onde basidiomas foram encontrados. Cinco grupos funcionais foram reconhecidos: dois deles são formados por espécies de Phylloporia (P. spathulata em raízes vivas no solo e $P$. chrysita em tronco vivo), e três outros por outras espécies de outros gêneros, cada um deles caracterizado pela presença de uma das espécies dominantes, algumas subordinadas e várias raras.

Palavras-chave: Ecologia de Fungos; Grupos funcionais; Políporos decompositores de madeira

\section{Abstract}

Ecological studies have suggested that different groups of polypore species, acting as parasites and/ or saprophytes, degrade different types of woody substrates. These functional groups have different decay capabilities and hence different roles in ecosystems. The aim of this study was to describe the community (species composition and their functionality inferred on the basis of substrate preference) of wood-decaying polypores in 
the Atlantic Forest of Parque Nacional da Serra do Itajaí, in Santa Catarina State, Brazil. The polypore specimens and data on the substrates were sampled in two plots $(100 \times 50 \mathrm{~m})$. Among 152 specimens collected, 58 species were identified. Three main dominant groups were identified. The first group comprised three dominant species, the second group five subordinate species and the third 50 rare species. The species were ordered using cluster correspondence analysis based on relative frequency of the species in the different types of substrates and the mean size of the substrate where basidiomes were found. Five functional groups were recognized: two of them were formed by Phylloporia species (P. spathulata on living roots in the ground and P. chrysita on living trunk); and three others consisted of different species of different genera, each of them characterized by the presence of one dominant, few subordinate and several rare species.

Key words: Fungal ecology; Functional groups; Wood-decay polypores

\section{Introduction}

Polypores constitute one of the main groups of wood-decay fungi. The diversity of wood-decay fungi of the Atlantic Forest has been approached by several authors (e.g., LOGUERCIO-LEITE et al., 2002; RYVARDEN; MEIJER, 2002; DRECHSLER-SANTOS et al., 2008). Recently, Baltazar and Gibertoni (2009) presented the most extensive literature list with 733 aphyllophoraceous species, of which more than $50 \%$ were polypores.

Despite their importance in the ecology of forests, there are few ecological studies about this group in the Atlantic Forest (e.g., COCKLE et al., 2012). Moreover, little is known about the functional diversity of this group of fungi in the Atlantic Forest. Ecological studies have suggested that different groups of polypore species, acting as parasites and/or saprophytes, degrade different types of woody substrates. These functional groups have distinct decay capabilities and perform different roles in ecosystems. Among the wood-decay fungi, Polyporaceae s.1., as well as some Corticiaceae s.1. and Hymenochaetaceae, have been considered well suited to study the key role of woody debris in old-growth forests (BADER et al., 1995).

Accordingly, Urcelay and Robledo (2004), on the basis of a study conducted in monospecific Alnus acuminata Kunt (Betulaceae) forests of the Yungas in northwestern Argentina, proposed that it is possible to recognize functional groups of polypores according to the preferences of the species for particular types of substrate. The authors recognized groups of species that are directly related to different types of substrates (trunks and branches/twigs of trees living or dead, standing or on the ground and of different volumes) as well as different decay stages.

The polypore functional groups proposed by Urcelay and Robledo (2004) should be tested in a highly diverse ecosystem, such as the Atlantic Forest of Brazil. This domain is a diversified mosaic, showing distinguishable structures and floristic composition, due to the differences in soil, topography and climate characteristics in the broad area of occurrence in Brazil. The plant species diversity estimated for the Atlantic Forest is around 20,000, of which 55\% are trees (MITTERMEIER et al., 1999; CAPOBIANCO, 2001). This high diversity provides a large number of niches with different variables (humidity, temperature, volume and diameter of trunks and branches, stage of decomposition of wood, and physical and chemical structure of dead trees), which may influence the functional diversity and community structure of wooddecay fungi (RAYNER; TODD, 1979).

The aim of this study was to describe and characterize the community of wood-decay polypores of the Parque Nacional da Serra do Itajaí (PARNA-SI), in the Atlantic Forest of Santa Catarina State, Brazil, in terms of richness and abundance, and to infer their functionality using substrata/hosts.

\section{Materials and Methods}

\section{Study area}

The Parque Nacional da Serra do Itajaí (PARNASI) is located in the Itajaí Valley, in Santa Catarina State (Figure 1A), covering an area of 57,374 ha and 
FIGURE 1: Study area: (A) PARNA Serra do Itajaí in Santa Catarina State, with study area outlined (the square represents the Parque Natural Nascentes do Garcia enlarged in B); (B) Parque Natural Nascentes do Garcia showing the positions of plots.

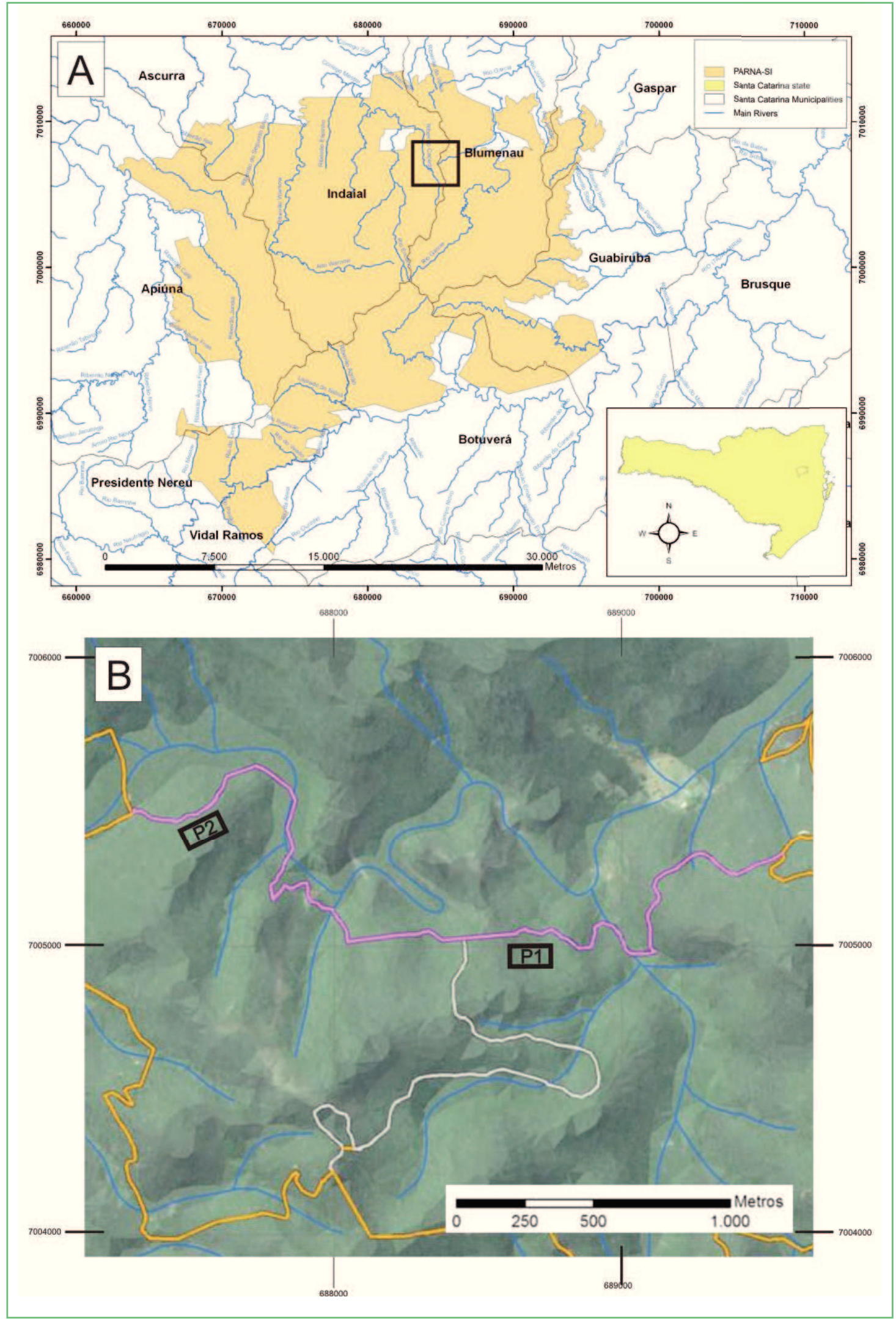


with altitudes from 80 to 1039 m.a.s.l. The climate is temperate humid with warm summers (Cfa), and there is significant precipitation in all seasons (GAPLAN, 1986). The annual mean temperature ranges between 17 and $22^{\circ} \mathrm{C}$, and the annual rainfall ranges between 1600 and $1800 \mathrm{~mm}$, distributed between 120 and 140 days of rain during the year. The mean relative humidity is between 75 and 85\% (KLEIN, 1979). This conservation area comprises a significant portion of the remnants of the Atlantic Forest domain, with patches of primary forests and others in advanced stages of regeneration (source: SOS Mata Atlântica and INPE Instituto Socioambiental). The study was conducted in the Parque Municipal Natural Nascentes do Garcia (extending from $27^{\circ} 01^{\prime}$ to $27^{\circ} 06^{\prime} \mathrm{S}$ and from $49^{\circ} 06^{\prime}$ to $\left.49^{\circ} 10^{\prime} \mathrm{W}\right)$, Blumenau municipality, where two sample areas of $5000 \mathrm{~m}^{2}(100 \times 50 \mathrm{~m})$ were plotted (Figure 1B). The vegetation in the study area is classified as dense ombrophilous forest (GAPLAN, 1986).

\section{Sampling methods}

Each plot (Figure 1B) was sampled four times (field expeditions: November 5-6, 2011; February 22-23, 2012; June 11-12, 2012; and September 12-13, 2012) to cover the seasons of one year.

All basidiomes of polypore species were recorded and all of the same species in the same substrate were recorded as one occurrence sampled. Substrates were identified to avoid recording the same specimens during different field expeditions. The following substrate data were recorded for each fungal occurrence: diameter and length (volume of the substrate was then calculated), and the condition [living trunk (LT); dead trunk (DT): standing or fallen logs and stumps; living branch (LB); dead branch (DB); and on the ground (OG)].

According to Urcelay and Robledo (2004), in the present study, it was assumed that there was a gradient in the diameter and volume of the logs and a gradient in the level of decay, ranging from the dead trunks to living in the soil, representing a decay succession.

\section{Data analysis}

Estimated richness was calculated with $\mathrm{ACE}$ and CHAO1 estimators, with one individual-based frequency sample (all polypore species frequency records across all sampling plots and dates), using the software EstimateS. These estimators were selected because they are nonparametric estimators that do not assume the distribution type of the dataset, do not fit a particular model and are based on abundance data (Version 9.0, viceroy.eeb. uconn.edu/estimates).

The relative frequency of each polypore species in each substrate condition was calculated as $F r_{x i}=\frac{n_{x i}}{A x}$, where " $\mathrm{n}_{\mathrm{xi}}$ " is the number of occurrences of each polypore species " $x$ " in each substrate condition "i" (viz., LT, DT, LB, DB, and OG) and where "Ax" is abundance of polypore species " $\mathrm{x}$ " (across all sampling plots and dates). The species richness in each substrate condition was also calculated.

Cluster analyses were performed to classify polypore species into groups as recommended by Goodall (1980). This method is based on distances between species and combines the species computed from their relative frequency in different substrate conditions $\left(\mathrm{Fr}_{\mathrm{xi}}\right)$ and the average volume of the substrates on which they occurred. The mean Euclidean distance was used as a measure of similarity between species and clustering was based on the average linkage method using the Infostat statistical package (DI RIENZO et al., 2012). Species with two or more occurrences were included in the analysis (URCELAY; ROBLEDO, 2004).

The sampling effort was tested using complementarity (dissimilarity), an empirical measure of the degree of species uniqueness between different samples. This empirical test for complementarity was calculated as $C j k=\frac{U j k}{S j k}$, where " $\mathrm{Cjk}$ " is the complementarity between samples (or plots) " $\mathrm{j}$ " and " $k$ ", "Ujk" is the total number of taxa encountered in only one plot, and " $\mathrm{Sjk}$ " is the total richness of both plots combined (COLWELL; CODDINGTON, 1994). Sampling effort for species richness is most efficient when complementarity between samples (Cjk) is about 0.5 (LODGE et al., 2004). 


\section{Results}

\section{Species richness}

In the present study, 152 specimens were obtained, of which $94 \%$ (143) were identified at the species level, representing 58 polypore species. Eleven specimens (6\%) could not be identified at the species level, but they represented 11 distinct species among the polypore community (i.e., Dichomitus sp., Fomitiporella sp., Fuscoporia sp., Junghuhnia sp., Oxyporus sp., Phellinus sp. 1 and Phellinus sp. 2, Polyporus sp., Rigidoporus sp., Tyromyces sp. 1 and Tyromyces sp. 2), and were therefore included in the study. Species richness observed ( 58 species) represented $51 \%$ of the estimated richness according to $\mathrm{ACE}=114.1$ and $47 \%$ according to CHAO1 = 122.2 (Figure 2). Complementarity (dissimilarity) was $\mathrm{Cjk}=0.7$, showing that the sampling effort for richness was efficient.

\section{Community structure (abundance and richness of species)}

Community structure based on species abundance showed (Figure 3; Table 1) that Polyporus dictyopus Mont., Perenniporia martia (Berk.) Ryvarden, and Fuscoporia wahlbergii (Fr.) T. Wagner \& M. Fisch. were the dominant species with the highest abundance values $(15,13$ and 12 , respectively). They represented almost $26 \%$ of the total occurrences (40 out of 152 ) but only $5.4 \%$ of the species richness. At the other extreme, a group of rare species, mainly with one, two or three records (only two species with four records) represented around $50 \%$ of the total of occurrences (76/152); however, they covered $86 \%$ of species richness. With intermediate abundance values of six to nine records, a group of five subordinate species represented $24 \%$ of the total occurrences $(38 / 152)$ and $8.6 \%$ of species richness.

Abundance and species richness increased with decay stage of the substrate. Among 152 specimens collected, six (four species) were recorded on LT, 68 (22 species) on DT, 71 (40 species) on DB and seven (five species) on the ground (OG) (Figure 4; Table 1).

FIGURE 2: Observed S(est) and estimated richens by CHAO1 and ACE estimators. Estimators show different values.

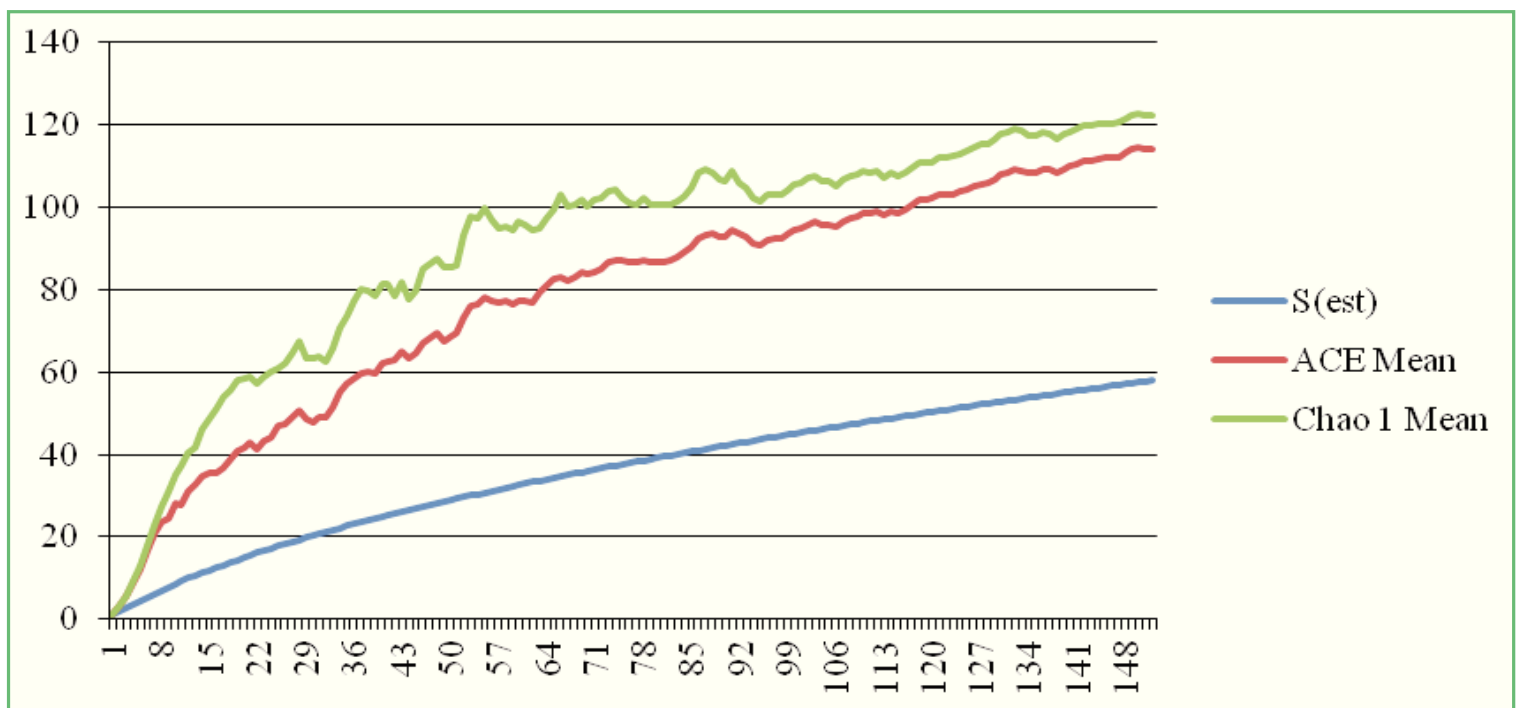


FIGURE 3: Abundance of species of the PARNA Serra do Itajaí: D. dominant species; S. subordinate species and R. rare species.

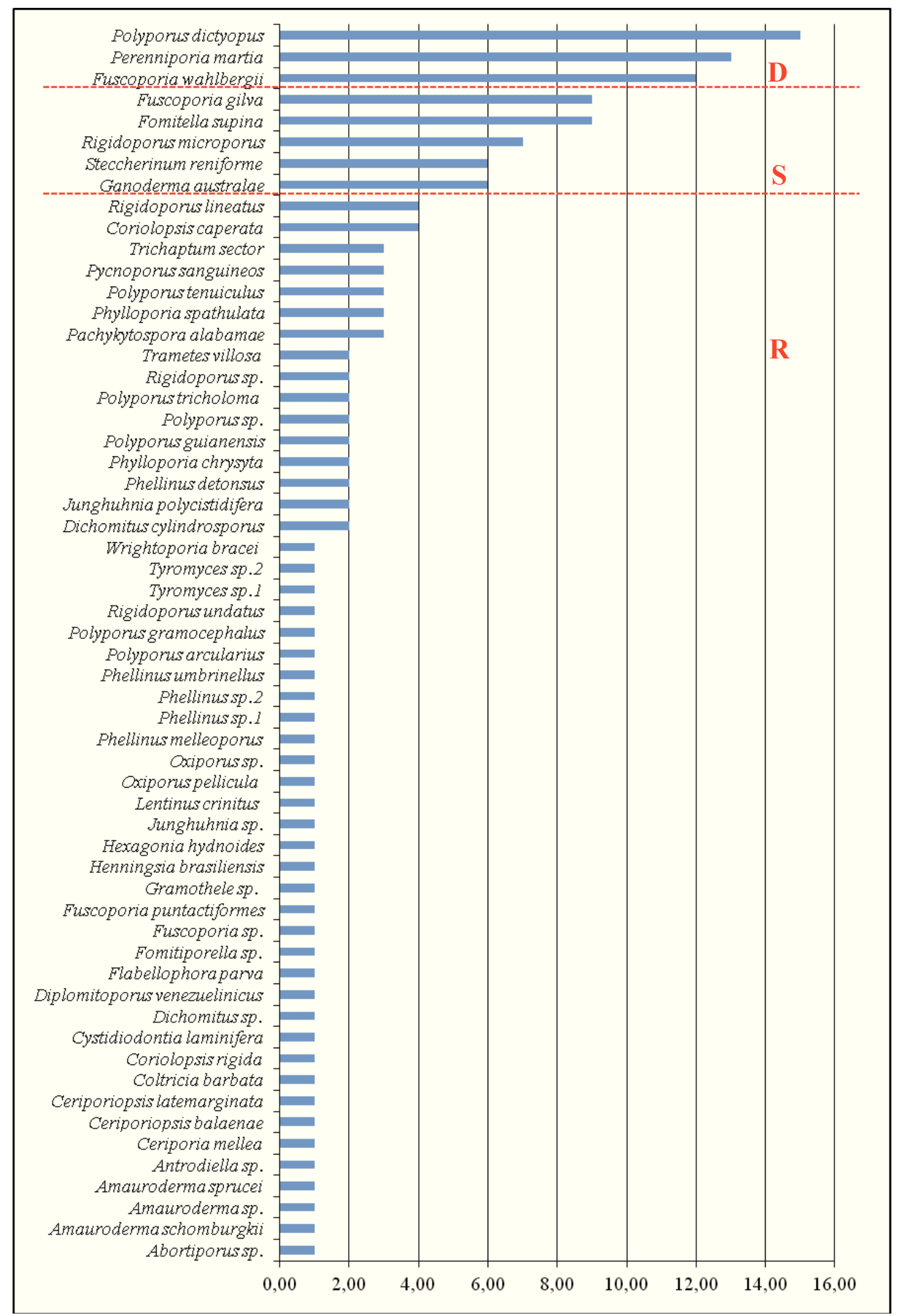


TABLE 1: Total relative frequency and number of polypore species in the substrate conditions and mean volume of the logs where they were found. $\mathrm{A}=$ abundance, $\mathrm{OG}=$ on ground, $\mathrm{LB}=$ living branch, $\mathrm{LT}=$ living trunk, $\mathrm{DB}=$ dead branch, DT $=$ dead trunk, $\bar{X}$ Vol. $\left(\mathrm{m}^{3}\right)=$ mean volume.

\begin{tabular}{|c|c|c|c|c|c|c|c|}
\hline \multirow{2}{*}{ Species } & \multicolumn{6}{|c|}{ Relative Frequency } & \multirow{2}{*}{$\bar{X}$ Vol. $\left(\mathbf{m}^{3}\right)$} \\
\hline & $\mathbf{A}$ & OG & LB & LT & DB & DT & \\
\hline Polyporus dictyopus & 15 & 0.00 & 0.00 & 0.00 & 0.67 & 0.33 & 0.175 \\
\hline Perenniporia martia & 13 & 0.00 & 0.00 & 0.00 & 0.00 & 1.00 & 1.567 \\
\hline Fuscoporia wahlbergii & 12 & 0.00 & 0.00 & 0.08 & 0.00 & 0.92 & 0.326 \\
\hline Fomitella supina & 9 & 0.00 & 0.00 & 0.00 & 0.33 & 0.67 & 0.744 \\
\hline Fuscoporia gilva & 9 & 0.00 & 0.00 & 0.00 & 0.44 & 0.56 & 0.935 \\
\hline Rigidoporus microporus & 7 & 0.00 & 0.00 & 0.00 & 0.29 & 0.71 & 1.094 \\
\hline Ganoderma australe & 6 & 0.00 & 0.00 & 0.33 & 0.00 & 0.67 & 0.056 \\
\hline Steccherinum reniforme & 6 & 0.00 & 0.00 & 0.00 & 0.67 & 0.33 & 0.247 \\
\hline Coriolopsis caperata & 4 & 0.00 & 0.00 & 0.00 & 0.25 & 0.75 & 1.168 \\
\hline Rigidoporus lineatus & 4 & 0.00 & 0.00 & 0.00 & 0.50 & 0.50 & 0.022 \\
\hline Pachykytospora alabamae & 3 & 0.00 & 0.00 & 0.00 & 1.00 & 0.00 & 0.001 \\
\hline Phylloporia spathulata & 3 & 1.00 & 0.00 & 0.00 & 0.00 & 0.00 & 0.000 \\
\hline Polyporus tenuiculus & 3 & 0.00 & 0.00 & 0.00 & 1.00 & 0.00 & 0.002 \\
\hline Pycnoporus sanguineus & 3 & 0.00 & 0.00 & 0.00 & 1.00 & 0.00 & 0.025 \\
\hline Trichaptum sector & 3 & 0.00 & 0.00 & 0.00 & 0.67 & 0.33 & 0.029 \\
\hline Dichomitus cylindrosporus & 2 & 0.00 & 0.00 & 0.00 & 1.00 & 0.00 & 0.002 \\
\hline Junghuhnia polycystidifera & 2 & 0.00 & 0.00 & 0.00 & 0.50 & 0.50 & 0.570 \\
\hline Phellinus detonsus & 2 & 0.00 & 0.00 & 0.50 & 0.00 & 0.50 & 0.173 \\
\hline Phylloporia chrysita & 2 & 0.00 & 0.00 & 1.00 & 0.00 & 0.00 & 0.001 \\
\hline Polyporus guianensis & 2 & 0.00 & 0.00 & 0.00 & 1.00 & 0.00 & 0.001 \\
\hline Polyporus sp. & 2 & 0.00 & 0.00 & 0.00 & 1.00 & 0.00 & 0.001 \\
\hline Polyporus tricholoma & 2 & 0.00 & 0.00 & 0.00 & 1.00 & 0.00 & 0.001 \\
\hline Rigidoporus sp. & 2 & 0.00 & 0.00 & 0.00 & 0.50 & 0.50 & 1.768 \\
\hline Trametes villosa & 2 & 0.00 & 0.00 & 0.00 & 1.00 & 0.00 & 0.001 \\
\hline Abortiporus sp. & 1 & 0.00 & 0.00 & 0.00 & 1.00 & 0.00 & 0.001 \\
\hline Amauroderma schomburgkii & 1 & 1.00 & 0.00 & 0.00 & 0.00 & 0.00 & 0.000 \\
\hline Amauroderma sp. & 1 & 1.00 & 0.00 & 0.00 & 0.00 & 0.00 & 0.000 \\
\hline Amauroderma sprucei & 1 & 1.00 & 0.00 & 0.00 & 0.00 & 0.00 & 0.000 \\
\hline Antrodiella sp. & 1 & 0.00 & 0.00 & 0.00 & 1.00 & 0.00 & 0.001 \\
\hline Ceriporia mellea & 1 & 0.00 & 0.00 & 0.00 & 1.00 & 0.00 & 0.001 \\
\hline Ceriporiopsis balaenae & 1 & 0.00 & 0.00 & 0.00 & 1.00 & 0.00 & 0.016 \\
\hline Ceriporiopsis latemarginata & 1 & 0.00 & 0.00 & 0.00 & 1.00 & 0.00 & 0.006 \\
\hline Coltricia barbata & 1 & 1.00 & 0.00 & 0.00 & 0.00 & 0.00 & 0.000 \\
\hline Coriolopsis rigida & 1 & 0.00 & 0.00 & 0.00 & 1.00 & 0.00 & 0.011 \\
\hline Cystidiodontia laminifera & 1 & 0.00 & 0.00 & 0.00 & 0.00 & 1.00 & 0.377 \\
\hline Dichomitus sp. & 1 & 0.00 & 0.00 & 0.00 & 1.00 & 0.00 & 0.003 \\
\hline Diplomitoporus venezuelicus & 1 & 0.00 & 0.00 & 0.00 & 0.00 & 1.00 & 1.256 \\
\hline Flabellophora parva & 1 & 0.00 & 0.00 & 0.00 & 1.00 & 0.00 & 0.000 \\
\hline Fomitiporella sp. & 1 & 0.00 & 0.00 & 0.00 & 1.00 & 0.00 & 0.004 \\
\hline Fuscoporia punctatiformes & 1 & 0.00 & 0.00 & 0.00 & 1.00 & 0.00 & 0.001 \\
\hline Fuscoporia sp. & 1 & 0.00 & 0.00 & 0.00 & 0.00 & 1.00 & 0.791 \\
\hline
\end{tabular}




\begin{tabular}{lccccccc}
\hline Grammothele sp. & 1 & 0.00 & 0.00 & 0.00 & 1.00 & 0.00 & 0.001 \\
Henningsia brasiliensis & 1 & 0.00 & 0.00 & 0.00 & 0.00 & 1.00 & 0.006 \\
Hexagonia hydnoides & 1 & 0.00 & 0.00 & 0.00 & 1.00 & 0.00 & 0.003 \\
Junghuhnia sp. & 1 & 0.00 & 0.00 & 0.00 & 1.00 & 0.00 & 0.001 \\
Lentinus crinitus & 1 & 0.00 & 0.00 & 0.00 & 1.00 & 0.00 & 0.001 \\
Oxyporus pellicula & 1 & 0.00 & 0.00 & 0.00 & 1.00 & 0.00 & 0.001 \\
Oxyporus sp. & 1 & 0.00 & 0.00 & 0.00 & 1.00 & 0.00 & 0.045 \\
Phellinus melleoporus & 1 & 0.00 & 0.00 & 0.00 & 0.00 & 1.00 & 1.360 \\
Phellinus sp.1 & 1 & 0.00 & 0.00 & 0.00 & 0.00 & 1.00 & 0.109 \\
Phellinus sp.2 & 1 & 0.00 & 0.00 & 0.00 & 0.00 & 1.00 & 0.035 \\
Phellinus umbrinellus & 1 & 0.00 & 0.00 & 0.00 & 0.00 & 1.00 & 0.814 \\
Polyporus arcularius & 1 & 0.00 & 0.00 & 0.00 & 1.00 & 0.00 & 0.026 \\
Polyporus grammocephalus & 1 & 0.00 & 0.00 & 0.00 & 1.00 & 0.00 & 0.014 \\
Rigidoporus undatus & 1 & 0.00 & 0.00 & 0.00 & 1.00 & 0.00 & 0.008 \\
Tyromyces sp.1 & 1 & 0.00 & 0.00 & 0.00 & 1.00 & 0.00 & 0.001 \\
Tyromyces sp.2 & 1 & 0.00 & 0.00 & 0.00 & 1.00 & 0.00 & 0.004 \\
Wrightoporia bracei & 1 & 0.00 & 0.00 & 0.00 & 1.00 & 0.00 & 0.001 \\
Species richness & & 5 & 0 & 4 & 39 & 23 & \\
Total abundance & 152 & & & & & & \\
\hline
\end{tabular}

FIGURE 4: Richness and relative abundance of polypore species of the PARNA Serra do Itajaí within different types of substrate. Different colored strips in each substrate condition represent different species. Thickness of each strip in each substrate type represents relative abundance. $\mathbf{O G}=$ on ground, $\mathbf{L T}=$ living trunk, $\mathbf{D T}=$ dead trunk, $\mathbf{D B}=$ dead branch. Green arrow indicates the gradient of decay stage from living hosts to dead substrates (trunks or branches).

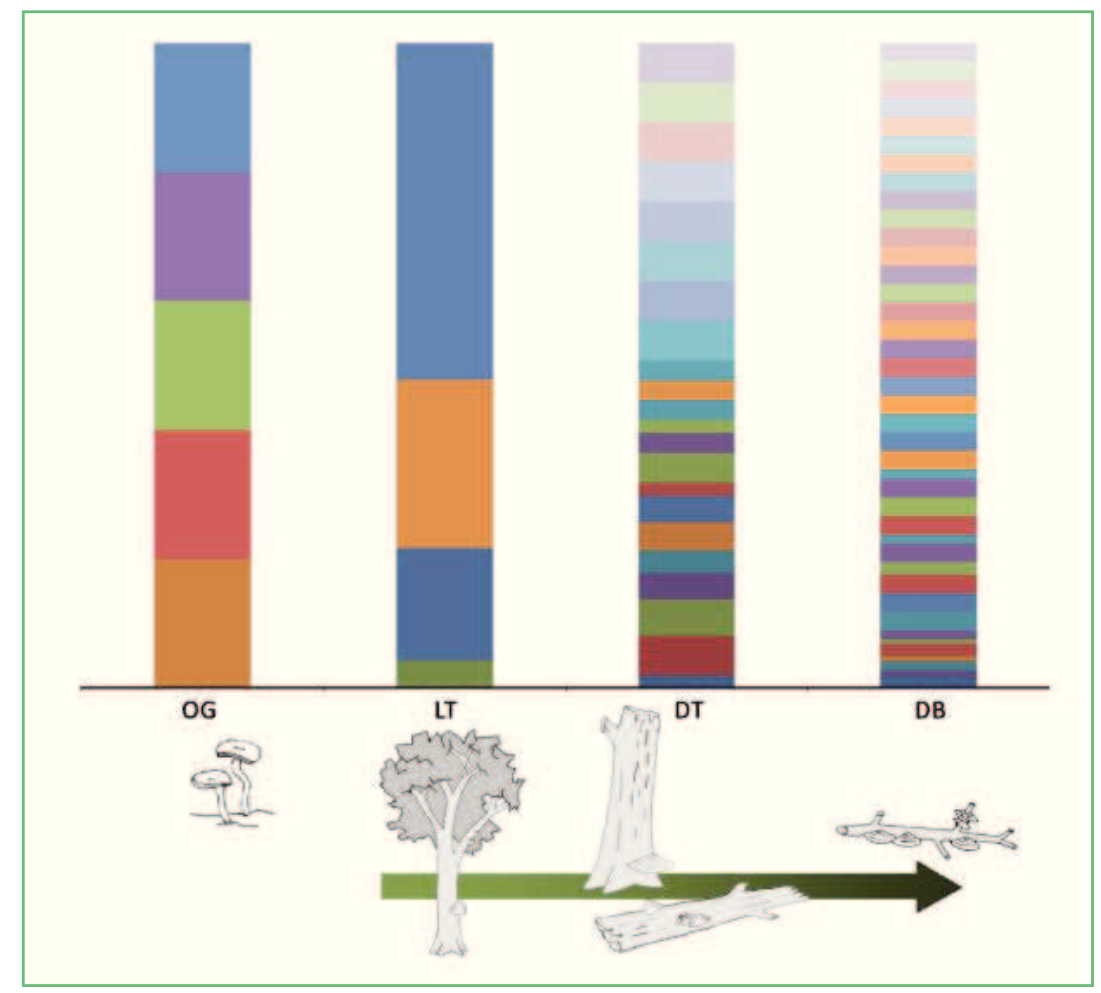




\section{Community structure (functional groups)}

On the basis of the relative frequency of each species on the different $\log$ conditions and the mean diameter and volume of the log on which the basidiomes were found, five main groups of polypore species were identified at 2.30 dendrogram distance of the cluster analysis (Figure 5). Phylloporia spathulata (Hook.) Ryvarden (with relative frequency of 1.00, OG) and Phylloporia chrysita (Berk.) Ryvarden (with relative frequency of 1.00 on LT of extremely small volume) formed two functional groups, Groups 1 and 2 , respectively.
Group 3 was formed by Ganoderma australe (Fr.) Pat., Phellinus detonsus (Fr.) Ryvarden and Fuscoporia wahlbergii. These species are able to cause decay and develop basidiomes in standing living trunks, but can also grow as saprophytes and then develop basidiomes on dead trunks.

Groups 4 and 5 consisted essentially of saprophytic species on decaying dead wood, and they were differentiated by the relative frequency and the average size of the substrates. Group 4 was formed by seven species that grow preferentially on dead trunks of large size; the largest volumes observed were in this group. Group 5 comprised 18 species that grew exclusively on dead branches of small volume. Within Group 5, two

FIGURE 5: Cluster analysis of different polypore species of the PARNA Serra do Itajaí based on relative frequency of the species in each substrate condition and the mean volume of the substrates where basidiomes were found. Arrows indicate dominant species. Species with two or more occurrences were included in the analysis.

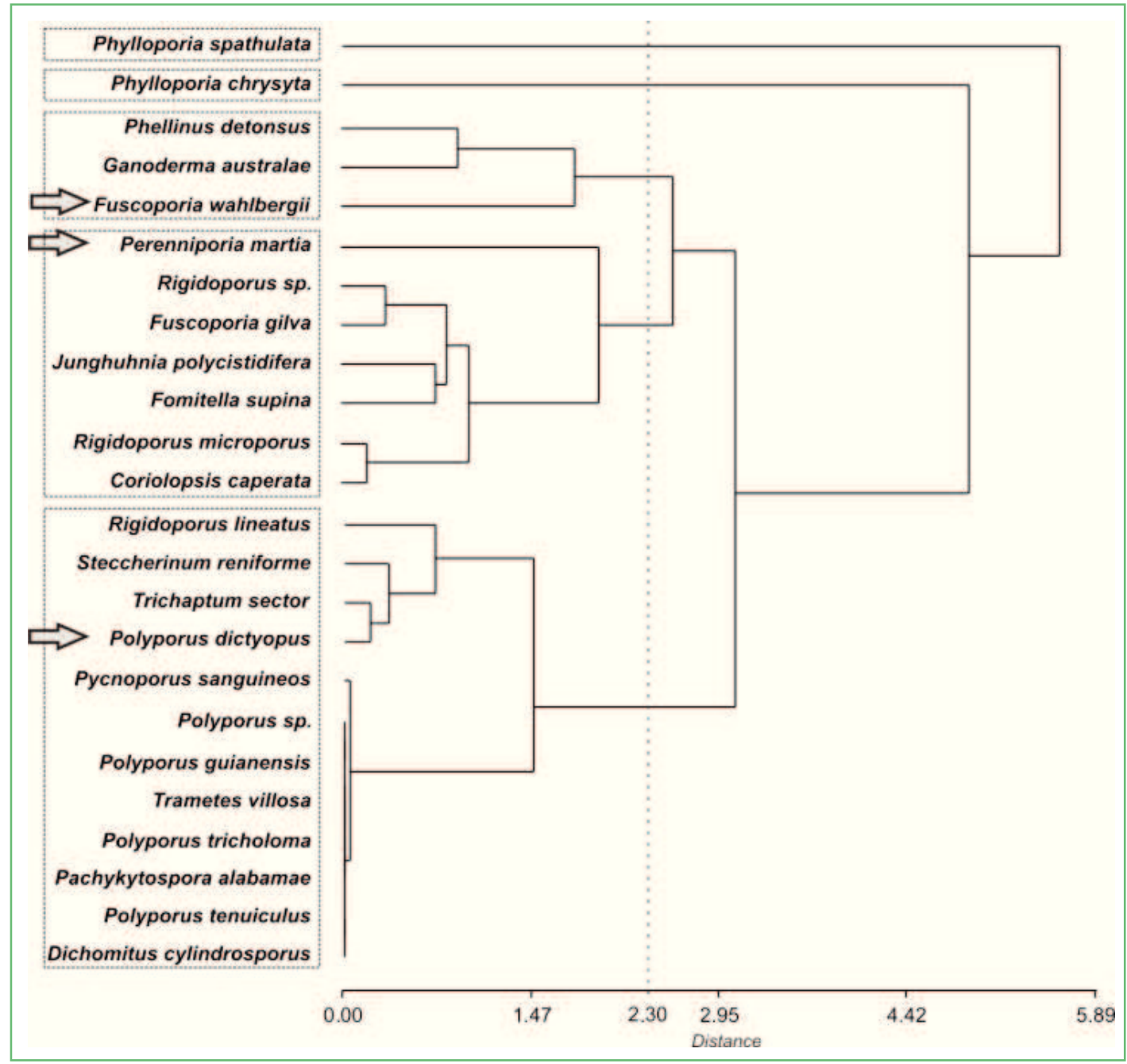


smaller subgroups could be distinguished. Rigidoporus lineatus (Pers.) Ryvarden, Steccherinum reniforme (Berk. \& M.A. Curtis) Banker, Trichaptum sector (Ehrenb.) Kreisel and Polyporus dictyopus formed a subgroup characterized by growing indifferently on DT and DB of relatively small volume. The other subgroup was composed of species that grew exclusively on DB with the smallest volumes. Regarding Groups 3 to 5, each group was composed of one dominant species, at least one subordinate and several rare species (only one in Group 3).

\section{Discussion}

This work was based on the occurrence of species through the presence of their basidiomes. We conducted the sampling over four seasons to consider the seasonal variability and to include as many species as possible. Our results and conclusions are conservative, since we underestimated the community by not considering all specimens that not developed basidiomes. However, presence-absence of basidiomes is a method accepted for ecological works (URCELAY; ROBLEDO, 2004).

Species richness observed (58) was near $50 \%$ of that estimated $(\mathrm{ACE}=114.1$ and $\mathrm{CHAO} 1=122.2$; Figure 1). This represents less than $16 \%$ observed and $31 \%$ estimated with ACE and 33\% estimated with CHAO1 of the ca. 365 polypore species reported by Baltazar and Gibertoni (2009) for the Atlantic Forest domain. Sampling effort was enough as suggested by the complementary index (LODGE et al., 2004); abundance and richness (Figure 4; Table 1) values would certainly be higher with more sampling effort (additional plots). However, we believe that dominance (Figure 3) and functional structures (Figure 5) would not change substantially. From a practical point of view, the sample design of this study was enough to get a preliminary overview of the community structure. Species richness and abundance increased as the decay stage increased (Figure 4). This is in accordance with previous results (URCELAY; ROBLEDO, 2004) and the theoretical frame of decay succession (RAYNER; TODD, 1979).

Regarding the functional structure of the community, our results agree with those of Urcelay and Robledo
(2004). We could identify two additional functional groups (Groups 1 and 2), both constituted by Phylloporia species, considered rare for the study area (Figure 3 ). Phylloporia species are parasites of roots in the ground, living branches and living stems of creepers (DECOCK et al., 2013). This genus is not present in the Alnus acumniata mountain forests where polypore functional groups were originally proposed (ROBLEDO et al., 2003; URCELAY; ROBLEDO, 2004). Although these groups are constituted by one single species each one, in the Atlantic Forest, there are more species that would have the same substrate preference and that consequently would integrate these groups. The same group of Phylloporia spathulata could include Amauroderma schomburgkii (Mont. \& Berk.) Torrend, Amauroderma sprucei (Pat.) Torrend, Amauroderma sp. and Coltricia barbata Ryvarden \& de Meijer, also recorded in the study area, and usually considered parasitic on roots of living trees (FURTADO, 1981; RYVARDEN, 2004). Groups 3-5 identified in this study agree with those proposed by Urcelay and Robledo (2004), however with a different species composition. Another interesting aspect, in accordance with those of Urcelay and Robledo (2004), is that each group was composed of at least one dominant, few subordinate and several rare species. Our results suggest that communities of polypores would have this dominance/functional structure regardless of the fungal species arrangement and the structural complexity of the ecosystem (i.e. diversity and abundance of woody substrates).

Ecological studies describing the community structure of the polypores, as presented here, are extremely important, in particular in regard to the current conservation issues that threaten the forest remnants. Particular substrates and/or key functional species could be identified, and then could be considered when conservation decisions are taken.

\section{Acknowledgments}

Maria A. Neves, Mateus A. Reck, Genivaldo A. Silva and an anonymous reviewer of Biotemas are kindly acknowledged for critically reading the manuscript and providing comments. We thank PARNA Serra do 
Itajaí (IBAMA/ICMBio) for access to the study area. CAPES provided a master's scholarship to MABS. This work is part of the project "Fungos poliporoides (Agaricomycetes) em Santa Catarina - PolíporosSC" (Botânica/UFSC No. 2011.0182). Dr. A. Leyva helped with English editing of the manuscript.

\section{References}

BADER, P.; JANSSON, S.; JONSOON, B. G. Wood-inhabiting fungi and substratum decline selectively logged boreal spruce forests. Biological Conservation, Boston, v. 72, p. 355-362, 1995. BALTAZAR, J. M.; GIBERTONI, T. B. A checklist of the aphyllophoroid fungi (Basidiomycota) recorded from the Brazilian Atlantic Rain Forest. Mycotaxon, Ithaca, v. 109, p. 439-442, 2009. CAPOBIAnCO, J. P. R. (Org.). Dossie Mata Atlântica 2001. Projeto Monitoramento Participativo da Mata Atlantica. São Paulo: Instituto Socioambiental, 2001. 407 p.

COCKLE, K. L.; MARTIN, K.; ROBLEDO, G. Linking fungi, trees, and hole-using birds in a neotropical tree-cavity network: pathways of cavity production and implications for conservation. Forest Ecology and Management, Amsterdam,v. 264, p. 210-219, 2012.

COLWELL, R. K.; CODDINGTON, J. A. Estimating terrestrial biodiversity through extrapolation. Philosophical Transactions of the Royal Society London, London, v. 345, p. 101-118, 1994.

DECOCK, C.; AMALFI, M.; ROBLEDO, G.; CASTILlO, G. Phylloporia nouraguensis, an undescribed species on Myrtaceae from French Guiana. Cryptogamie Mycologie, Paris, v. 34, p. 1527, 2013.

DI RIENZO, J. A.; CASANOVES, F.; BALZARINI, M. G.; GONZALEZ, L.; TABLADA, M.; ROBLEDO, C. W. InfoStat versión. Córdoba: InfoStat Group, Facultad de Ciencias Agropecuarias, Universidad Nacional de Córdoba, 2012.

DRECHSLER-SANTOS, E. R.; WARTCHOW, F.; BASEIA, I. G.; GIBERTONI, T. B.; CAVALCANTI, M. A. Q. Revision of the Herbarium URM I. Agaricomycetes from the semi-arid region of Brazil. Mycotaxon, Ithaca, v. 104, p. 9-18, 2008.
FURTADO, J. S. Taxonomy of Amauroderma (Basidiomycetes, Polyporaceae). Vol. 34. New York: Memoirs of the New York Botanical Garden, 1981. 104 p.

GAPLAN - GABINETE DE PLANEJAMENTO E COORDENAÇÃO GERAL. Atlas de Santa Catarina. Rio de Janeiro: Aerofoto Cruzeiro, 1986. 173 p.

GOODALL, D. W. Numerical classification. In: WHITTAKER, R. H. (Ed.). Classification of Plant Communities. The Hague, Dordrecht: Kluwer Academic Publishers Group, 1980. p.

247-286.

KLEIN, R. M. Ecologia da flora e vegetação do Vale do Itajaí. Sellowia, Itajaí, v. 31, n. 1, p. 9-164, 1979.

LODGE, D. J.; AMMIRATI, J. F.; O’DELL, T. E.; MUELLER, G. M. Terrestrial and lignicolous macrofungi. In: FOSTER, M. S.; BILLS, G. F.; MUELLER, G. M. (Ed.). Biodiversity of Fungi: inventory and monitoring methods. Elsevier Academic Press, San Diego, 2004. p. 127-172.

LOGUERCIO-LEITE, C.; RYVARDEN, L.; GROPOSO, C. Studies in Neotropical polypores 16. Rubroporus carneoporis genus \& species nova. Mycotaxon, Ithaca, v. 83, p. 223-227, 2002. MITTERMEIER, R. A.; MYERS, N.; MITTERMEIER, C. G.; GIL, P. R. Hotspots: earth's biologically richest and most endangered terrestrial ecoregions. Mexico City: CEMEX, 1999. 130 p.

RAYNER, A. D. M.; TODD, N. K. Population and community structure and dynamics of fungi in decaying wood. Advanced Botany Research, Oxford, v. 7, p. 333-420, 1979.

ROBLEDO, G. L.; URCELAY, C.; RAJCHENBERG, M.; DOMÍNGUEZ, L. Políporos (Aphyllophorales, Basidiomycota) parásitos y saprófitos de Alnus acuminata en el noroeste argentino. Boletín de la Sociedad Argetina de Botánica, Córdoba, v. 38, p. 207-224, 2003.

RYVARDEN, L. Neotropical polypores. Part 1: Introduction, Ganodermataceae \& Hymenochaetaceae. Synopsis Fungorum, Oslo, v. 19, p. 45-64, 2004.

RYVARDEN, L.; MEIJER, A. A. R. Studies in neotropical polypores 14. New species from the state of Paraná, Brazil. Synopsis Fungorum, Oslo, v. 15, p. 34-69, 2002.

URCELAY, C; ROBLEDO, G. Community structure of polypores (Basidiomycota) in Andean Alder wood in Argentina: functional groups among wood-decay fungi? Austral Ecology, Alice Springs, v. 29, n. 4, p. 471-476, 2004. 